\title{
Mit dyplomacji pingpongowej w świetle przyszłych prób wykorzystania sportu w celu kreacji zbliżenia międzynarodowego ${ }^{1}$
}

Prezentowany artykuł poświęcony jest słynnej dyplomacji pingpongowej, do jakiej doszło pomiędzy Chińską Republiką Ludową a Stanami Zjednoczonymi na początku lat 70. To wydarzenie, które często postrzegane jest jako swoisty pierwowzór dyplomacji sportowej obejmującej kreację zbliżenia pomiędzy państwami przy wykorzystaniu sportu. Kiedy dyskutuje się o następstwach dyplomacji pingpongowej, najczęściej zwraca się uwagę na przełom w stosunkach amerykańsko-chińskich, anulowanie amerykańskiego embarga na handel z Chinami, wejście ChRL do ONZ czy nawiązanie po kilku latach stosunków dyplomatycznych pomiędzy dwoma zaangażowanymi krajami. Celem artykułu jest natomiast analiza następstw tego wydarzenia sportowo-politycznego z nieco innej perspektywy, jako swoistego katalizatora dla kolejnych prób nawiązania bliższych relacji Stanów Zjednoczonych z państwami, które można określić jako nieprzyjazne.

Przedstawiane badanie stanowi próbę odpowiedzi na pytanie dotyczące wytworzenia się w świadomości zbiorowej społeczeństwa amerykańskiego mitu

* Doktor, Uniwersytet Łódzki, Wydział Studiów Międzynarodowych i Politologicznych, Katedra Teorii Polityki i Myśli Politycznej.

1 Badanie zostało sfinansowane przez Narodowe Centrum Nauki w ramach projektu nr 2015/19/D/HS5/00513. 
dyplomacji pingpongowej jako narzędzia dyplomatycznego umożliwiającego poprawę relacji z innymi państwami przez Stany Zjednoczone. Weryfikacji zostanie w związku z tym poddana hipoteza, zgodnie z którą przełom w stosunkach amerykańsko-chińskich, do którego przyczyniła się dyplomacja pingpongowa, wywarł na społeczeństwie amerykańskim tak wielkie wrażenie, iż można ją rozpatrywać w kategoriach mitu politycznego. Sukces dyplomacji pingpongowej rozbudził bowiem w Stanach Zjednoczonych duże nadzieje związane z możliwością politycznego dyskontowania międzynarodowego sportu, a także $\mathrm{z}$ ogólnym rozwojem dyplomacji publicznej w tym kraju. W tym kontekście można mówić o micie dyplomacji pingpongowej.

W pierwszej części artykułu w krótki sposób opisany zostanie przebieg i bezpośrednie następstwa dyplomacji pingpongowej pomiędzy Stanami Zjednoczonymi a Chinami, natomiast $\mathrm{w}$ drugiej części analizie będą poddane kolejne próby wykorzystania sportu w USA w celu nawiązania bliższych stosunków z Kubą z perspektywy ich związków z dyplomacją pingpongową. Przedstawione zostaną także inne sposoby nawiązywania do dyplomacji pingpongowej - poprzez kolejne obchody jej rocznic. Analiza realizowana będzie przy zastosowaniu metody hermeneutycznej, co wiąże się z koniecznością interpretowania motywacji inicjatorów oraz decydentów politycznych zaangażowanych w realizację poszczególnych nawiązań do dyplomacji pingpongowej.

\section{Dyplomacja pingpongowa. Przebieg i następstwa}

Zdecydowanie najbardziej znanym i najczęściej przytaczanym przez naukowców przykładem dyplomacji sportowej w ogóle jest tzw. dyplomacja pingpongowa, która miała miejsce pomiędzy Stanami Zjednoczony a Chińską Republiką Ludową. Chiny, państwo komunistyczne, nie utrzymywało bliższych relacji z państwami zachodnimi, jednak w obliczu konfliktu ze Związkiem Radzieckim pojawiła się tam chęć poszukiwania możliwości otworzenia się na relacje międzynarodowe, $w$ tym zbliżenia z USA. Chociaż strategicznie pozycja Stanów Zjednoczonych była na początku lat 70. zgoła inna, to nie można powiedzieć, iż to jedynie ChRL pozostawała zainteresowana nawiązaniem z nimi bliższych relacji. Wielu badaczy wskazuje, iż Amerykanom również zależało na możliwości zbliżenia z Chińczykami, szczególnie po objęciu prezydentury w USA przez Richarda Nixona. Ten prezydent jeszcze przed objęciem urzędu twierdził, iż Stany Zjednoczone muszą przeorientować swoją politykę względem Chin $^{2}$. Chęć zbliżenia amerykańsko-chińskiego była zatem dwustronna.

T.F. Carter, J. Sugden, The USA and Sporting Diplomacy: Comparing and Contrasting the

Cases of Table Tennis with China and Baseball with Cuba in the 1970s, „International 
Sytuacja pozostawała jednak skomplikowana i trudne byłoby zwyczajne nawiązanie stosunków dyplomatycznych. Chiny były bowiem krajem komunistycznym, Stany Zjednoczone zaś głównym ośrodkiem świata zachodniego. Sam ten fakt sprawiał, iż utrudnione byłoby zbliżenie tradycyjnymi kanałami dyplomatycznymi. Istotny okazał się także wątek związany z Republiką Chińską (Tajwanem). USA utrzymywały w tym czasie stosunki dyplomatyczne właśnie z tym krajem, a także umieszczały tam swoje wojsko. Tymczasem dwa państwa chińskie były wobec siebie wrogo nastawione do tego stopnia, iż odmawiały przynależenia do organizacji międzynarodowych, do których należało drugie z nich. Zatem i w tym kontekście Amerykanie zmuszeni byli do bardzo ostrożnych działań.

Od początku lat 70. podejmowano kroki zorientowane na nawiązanie politycznych relacji pomiędzy USA a ChRL, w pierwszej kolejności aby zaaranżować amerykańsko-chińskie spotkanie na wysokim poziomie. Miało to formę dyplomacji tajnej i odbywało się najczęściej poprzez tzw. kanał pakistański, za pośrednictwem którego przekazywano listy. Właśnie tą drogą doszło do pierwszych propozycji ze strony ChRL, aby do Pekinu udał się na rozmowy specjalny przedstawiciel prezydenta USA, sekretarz stanu lub nawet sam prezydent. Rozmowy zmierzały w kierunku zaaranżowania tajnego spotkania, podczas którego poczyniono by przygotowania do oficjalnych rozmów. Richard Nixon miał naciskać na ową tajność właśnie ze względu na obawę, iż gdyby informacja o spotkaniu wyszła na jaw, tajwańskie lobby w USA mogłoby uniemożliwić zbliżenie ${ }^{3}$. Warto dodać, iż wspomniany kanał pakistański nie był pierwszą drogą, za pośrednictwem której Waszyngton próbował nawiązać kontakt z Pekinem. Wcześniej próbowano także skorzystać z pomocy dyplomatów holenderskich i francuskich, w obu przypadkach bezskutecznie. Ponadto obie strony czyniły w tym czasie różne gesty dobrej woli, np. w grudniu 1970 roku na pierwszej stronie chińskiego „Dziennika Ludowego” ukazało się zdjęcie Mao Zedonga wraz z jego przyjacielem, amerykańskim dziennikarzem Edgarem Snowem, na placu Tiananmen, opatrzone komentarzem: „Ludzie z całego świata, w tym Amerykanie, są naszymi przyjaciółmi”. Nota bene podczas tego spotkania Mao miał powiedzieć Snowowi, iż chciałby zaprosić Nixona do Pekinu. Ukazuje to istotę prowadzenia dyplomacji sportowej jako instrumentu umożliwiającego podjęcie właściwej dyplomacji. W opisanej sytuacji niezwykle trudne, jeśli w ogóle możliwe, było nawiązanie otwartych rozmów, i to pomimo faktu, iż

Relations" 2011, no. 26, s. 103.

3 X. Yafeng, Negotiating with the Enemy. U.S. - China Talks during the Cold War, 19491972, Bloomington 2006, s. 154-155.

4 Xu Guoqui, Olympic Dreams. China and Sports 1895-2008, Cambridge-London 2008, s. $120,123$. 
wola w tym kierunku była obustronna, a także podjęto już kontakt drogą tajną, za pośrednictwem dyplomatów pakistańskich. Aby przyspieszyć rozwój wydarzeń, niezbędny okazał się „nietuzinkowy krok”, którym miała okazać się dyplomacja pingpongowa.

Bezpośrednim wstępem do późniejszej dyplomacji pingpongowej był udział chińskiej drużyny w XXXI Mistrzostwach Świata w Tenisie Stołowym, które odbywały się w japońskiej Nagoi w marcu i kwietniu 1971 roku. Warto wspomnieć, iż w tym czasie, w związku z konfliktem z Tajwanem, ChRL nie należała do większości międzynarodowych federacji sportowych, po tym jak w 1958 roku z nich wystąpiła ${ }^{5}$. Zachowała jednak członkostwo w Światowej Federacji Tenisa Stołowego, odpowiedzialnej za organizację mistrzostw świata $w$ tej dyscyplinie sportu. Mimo to komunistyczne Chiny nie uczestniczyły w dwóch poprzednich edycjach mistrzostw. Poprzedzając chiński udział w nich w 1971 roku, silnie zaangażowany w dyplomację sportową premier Chin Zhou Enlai spotkał się w ChRL z prezydentem Japońskiego Związku Tenisa Stołowego Kojim Goto, w celu poczynienia uzgodnień dotyczących udziału Chin w mistrzostwach. Problem stanowił bowiem fakt, iż Tajwan był członkiem Azjatyckiej Federacji Tenisa Stołowego, podczas gdy Chińczycy stosowali politykę, zgodnie z którą członkostwo w jakiejkolwiek międzynarodowej organizacji sportowej pozostawało możliwe tylko wówczas, gdy jej członkiem nie był Tajwan. Niemniej Zhou Enlaiowi i Kojiemu Goto udało się dojść do porozumienia i Chiny miały wziąć udział w mistrzostwach, co ogłoszono w „Dzienniku Ludowym” 2 lutego $1971 \mathrm{roku}^{6}$. Trzeba jednak pamiętać, iż w chińskim kierownictwie nie było zgodności co do słuszności wysyłania reprezentacji do Japonii. Zwolennikami tego rozwiązania byli Mao Zedong i Zhou Enlai, podczas gdy przeciwne głosy płynęły z Ministerstwa Spraw Zagranicznych i Państwowej Komisji Kultury Fizycznej i Sportu. Chiński przywódca był jednak zdecydowany, aby skorzystać z możliwości, jaką dawał sport, zdecydował zatem, że reprezentacja ChRL powinna pojechać do Nagoi ${ }^{7}$.

Chińska Republika Ludowa wzięła zatem udział w XXXI Mistrzostwach Świata w Tenisie Stołowym w japońskiej Nagoi. Bezpośrednio przed wyruszeniem miała miejsce sytuacja, która obrazuje instrumentalne podejście chińskiego kierownictwa do sportu w związku z możliwością jego dyplomatycznego wykorzystania. Podczas uroczystości pożegnania zawodników w Wielkiej Hali Ludowej premier Zhou Enlai miał poprosić reprezentantów, aby kierowali

5 Ibidem, s. 86; R. Espy, The Politics of the Olympic Games. With Epilogue, 1976-1980, Berkeley-Los Angeles-London 1981, s. 63.

6 Xu Guoqui, op. cit., s. 127; R. Espy, op. cit., s. 127-128.

7 Xia Yafeng, op. cit., s. 153. 
się duchem: „najpierw przyjaźń, potem rywalizacja”. Chiński rząd wydał także szereg instrukcji odnośnie do kontaktów z Amerykanami, m.in. Chińczykom nie wolno było witać się pierwszym ani wymieniać się flagami w przypadku bezpośrednich pojedynków, dozwolony był natomiast uścisk dłoni ${ }^{8}$. Biorąc pod uwagę późniejsze rozstrzygnięcia, wspomniane instrukcje dla chińskich reprezentantów mogą wydać się zaskakujące lub też sugerować brak wcześniejszego planu zaproszenia Amerykanów do Chin.

$\mathrm{W}$ trakcie mistrzostw w tenisie stołowym miało dojść do rozmowy chińskiego mistrza świata Zhuang Zedonga z członkiem drużyny amerykańskiej Glennem Cowanem, zaś okazją do tego miała być okoliczność, w której Amerykanin spóźnił się na autobus własnej drużyny, w związku z czym został podwieziony przez Chińczyków. Zawodnicy wymienili się prezentami, zaś następstwem tego kontaktu miała być propozycja ze strony Chińczyka, aby zorganizować chińsko-amerykańskie spotkanie graczy w tenisa stołowego w sytuacji braku stosunków dyplomatycznych pomiędzy obydwoma krajami ${ }^{9}$. Pomiędzy autorami nie ma jednak zgodności co do konkretnej formy sformułowania zaproszenia. Wiele wskazuje, iż to Amerykanie poszukiwali możliwości otrzymania zaproszenia do Chin w sytuacji, kiedy inne kraje takie zaproszenie dostały (np. Kanada i Kolumbia), jednak raczej nie miało to charakteru oficjalnego stanowiska drużyny ${ }^{10}$. W związku z tym można domniemywać, iż brak precyzyjnych informacji odnośnie do przebiegu samego zaproszenia był częścią planu nawiązującego do wspomnianej wcześniej chęci zachowania amerykańsko-chińskich kontaktów w tajemnicy. Jest to jednak jedynie spekulacja, nieposiadająca wiarygodnego potwierdzenia w faktach.

6 kwietnia 1971 roku Pekin wystosował do drużyny amerykańskiej zaproszenie do odbycia tournée po Chinach. Zaproszenie zostało jednak poprzedzone nieoficjalną wizytą chińskiego przedstawiciela Song Zhonga w hotelu amerykańskiej drużyny, podczas której miał on spytać prezydenta Amerykańskiej Związku Tenisa Stołowego Ruffora Harrisona, „jak by zareagował na zaproszenie do Chin". Harrison wyraził jedynie obawę, czy młodszych zawodników będzie stać na zmianę terminu biletów lotniczych, jednak kwestią kosztów mieli się zająć Chińczycy. W związku z brakiem formalnych kontaktów dyplomatycznych ze strony amerykańskiej za decyzję odpowiadał specjalista ds. Chin w amerykańskiej ambasadzie w Tokio, który wyraził zgodę na wyjazd miała to być pierwsza amerykańska delegacja w Chinach od 1949 roku. Sam

\footnotetext{
Xu Guoqui, op. cit., s. 129.

9 G.A. Pigman, Contemporary Diplomacy, Cambridge 2010, s. 193.

$10 \mathrm{Xu}$ Guoqui, op. cit., s. 131; Xia Yafeng, op. cit., s. 153.
} 
prezydent Nixon miał przyjąć tę wiadomość z radością i od razu polecić wystawienie wiz dziennikarzom, aby mogli relacjonować tournée ${ }^{11}$.

W następstwie wcześniejszych wydarzeń, 10 kwietnia 1971 roku dziewięciu amerykańskich tenisistów stołowych wraz z czterema działaczami i dwoma osobami towarzyszącymi zawodnikom przekroczyło most łączący Hongkong z Chinami kontynentalnymi. Amerykanie odwiedzili Pekin, Szanghaj i Hangzhou i rozegrali dwa mecze towarzyskie ${ }^{12}$. Zostali przyjęci bardzo ciepło i entuzjastycznie, w co osobiście zaangażowany był premier Zhou Enlai. Kulminacją wizyty miało być spotkanie premiera z drużyną chińską, amerykańską oraz czterema innymi w Wielkiej Hali Ludowej 14 kwietnia, podczas którego powiedział: „Wasza wizyta otworzyła nowy rozdział w historii stosunków pomiędzy Chińczykami i Amerykanami”. Kilka godzin później Waszyngton ogłosił zniesienie trwającego od 22 lat embarga na handel z Chinami, zezwolenie na handel towarami będącymi bliskim ekwiwalentem do tych, którymi handlowano ze Związkiem Radzieckim, zakończenie kontroli amerykańskiej waluty w odniesieniu do Chin oraz ułatwienia wizowe dla Chińczyków chcących odwiedzić Stany Zjednoczone ${ }^{13}$.

Dalsze wydarzenia działy się niezwykle szybko. W lipcu 1971 roku sekretarz stanu USA Henry Kissinger złożył wizytę w Chinach, podczas której rozmawiał z premierem Zhou Enlaiem. Wizyta była tajna, ale wkrótce R. Nixon podał informacje o niej do publicznej wiadomości. Podjęto także przygotowania do wizyty samego prezydenta USA w Pekinie. W październiku 1971 roku Kissinger ponownie udał się do ChRL, tym razem już publicznie. Wówczas ustalono szczegóły wizyty Nixona, a zaraz potem przeprowadzono w Chinach kampanię wyjaśniającą społeczeństwu zmianę w stosunkach z USA. Richard Nixon przybył ostatecznie do Chińskiej Republiki Ludowej 21 lutego 1972 roku. Podczas tej wizyty podpisano dokument określany jako nieformalne porozumienie strategiczne pomiędzy dwoma krajami ${ }^{14}$. Jeszcze wcześniej, bowiem już w październiku 1971 roku, komunistyczne Chiny zostały przyjęte do Organizacji Narodów Zjednoczonych, w miejsce Tajwanu. Jak widać, polityczne następstwa dyplomacji pingpongowej były niezwykle doniosłe.

11 E. Ladley, Nixon's China Trip, Lincoln 2002, s. 108; N. Griffin, Ping-Pong Diplomacy. The Secret History Behind the Game that Changed the World, New York 2014, s. 197.

12 A. Axelrod, The Real History of the Cold War. A New Look at the Past, New York 2009, s. 378; Xu Guoqui, op. cit., s. 135.

13 Xia Yafeng, op. cit., s. 153-154; G.A. Pigman, op. cit., s. 193.

14 J.S. Goldstein, J.R. Freeman, Three-Way Street. Strategic Reciprocity in World Politics, Chicago 1990, s. 109-111. 
Mit dyplomacji pingpongowej w świetle przyszłych prób wykorzystania sportu...

\section{Narodziny mitu}

Wydarzenia związane z dyplomacją pingpongową zostały uznane za ogromny sukces dyplomatyczny i większość obserwatorów podziela pogląd, iż był to ważny krok na drodze do pełnej normalizacji stosunków między dwoma krajami osiem lat później ${ }^{15}$. Wspominany wielokrotnie Zhou Enlai powiedzieć miał w ich kontekście, iż „nigdy wcześniej w historii sport nie został w tak efektywny sposób wykorzystany jako narzędzie międzynarodowej dyplomacji"16. Stwierdzono ponadto, iż „Chińczycy nauczyli się z dyplomacji pingpongowej, że sport i polityka są nierozłączne. [...] Sportowcy wzięli na siebie wielką odpowiedzialność. Są naszymi politycznymi ambasadorami”. Warto w związku z tym wspomnieć, iż Chińczycy także w późniejszym czasie wykorzystywali sport do zacieśniania więzów politycznych $z$ innymi państwami. Niejednokrotnie sportowcy chińscy otrzymywali instrukcje, aby przegrywać wybrane pojedynki, głównie z państwami komunistycznymi, w celu pogłębienia przyjaźni. Chiny budowały także stadiony w państwach Trzeciego Świata, poszukując sposobów na zbliżenie z nimi ${ }^{17}$.

Jak widać, dyplomacja pingpongowa w zaledwie kilka dni bardzo mocno zmieniła polityczny klimat dla kontaktów pomiędzy Stanami Zjednoczonymi a Chińską Republiką Ludową. Kiedy rozpatruje się ją w kategoriach mitu, to jego uobecnienie się jest zauważalne przede wszystkim w Stanach Zjednoczonych, aczkolwiek oczywiście także i w Chinach docenia się jej donośność. W dalszej części artykułu przeprowadzona zostanie analiza następstw dyplomacji pingpongowej w USA, dzięki którym wydarzenie to może być rozpatrywane w kategoriach mitu.

O mitycznym znaczeniu dyplomacji pingpongowej w USA świadczyć może wiele argumentów. Jeśli chodzi o kulturę masową, wydarzenie to zostało upamiętnione chociażby w filmie fabularnym Forrest Gump. Nawiązywali do niego także politycy w odniesieniu do relacji Stanów Zjednoczonych z Chinami. W lutym 2002 roku prezydent USA George W. Bush wspomniał dyplomację pingpongową podczas swojej drugiej wizyty w Chinach ${ }^{18}$. Chociaż aspekty

15 A.L. Johns, Introduction. Competing in the Global Arena: Sport and Foreign Relations since 1945, [w:] Diplomatic Games. Sport, Stagecraft, and International Relations since 1945, H.L. Dichteri, A.L. Johns (red.), Lexington 2014, s. 2.

16 C. Bjola, M. Kornprobst, Understanding International Diplomacy. Theory, Practice and Ethics, Abingdon 2013, s. 91

17 Fang Hong, Xiong Xiaozheng, Communist China: Sport, Politics and Diplomacy, [w:] Sport in Asian Society. Past and Present, J.A. Mangan, F. Hong (red.), Oxon-New York 2003, s. 335-337.

18 D.A. DeVoss, Ping-Pong Diplomacy, „Smithsonian Magazine” 2002, http://www.smithsonianmag.com/history/ping-pong-diplomacy-60307544/?no-ist [dostęp: 6.06.2016]. 
takie stanowią oczywiście argumenty przemawiające na rzecz hipotezy o mitycznym znaczeniu dyplomacji pingpongowej, w niniejszej analizie uwaga skupiona będzie na próbach powtórzenia sukcesu dyplomacji pingpongowej oraz na licznych wydarzeniach upamiętniających ją.

\section{Próby powtórzenia sukcesu dyplomacji pingpongowej}

Przełom, jaki dokonał się w stosunkach amerykańsko-chińskich za sprawą dyplomacji pingpongowej, odbił się w Stanach Zjednoczonych takim echem, że w kolejnych latach pojawiały się inicjatywy ponownego wykorzystania sportu w celu zmiany stanu stosunków pomiędzy USA a innym krajem, z którym łączyły je wrogie relacje. Chodzi mianowicie o stosunki z Kubą.

Relacje Stanów Zjednoczonych i Kuby wydają się w wielu elementach przypominać te, które łączyły USA z Chinami w okresie dyplomacji pingpongowej. Obydwa kraje nie utrzymywały bowiem stosunków dyplomatycznych po tym, jak w 1961 roku Amerykanie je zerwali. Wcześniej, w 1959 roku partyzantka narodowa Fidela Castro obaliła skorumpowany i utrzymujący na wyspie neokolonialną zależność od USA reżim Fulgencia Batisty. Następnie, nie mogąc zapewnić Kubie samowystarczalności, Castro przyjął pomoc radziecką, a niedługo potem, w kwietniu 1961 roku, rząd Stanów Zjednoczonych przygotował nieudaną akcję lądowania brygady antykomunistycznych imigrantów kubańskich w Zatoce Świń na Kubie, ukierunkowaną na obalenie reżimu Castro ${ }^{19}$. Władze obydwu krajów miały zatem wobec siebie wrogie nastawienie związane $\mathrm{z}$ antagonizmem ideologicznym. Było jednak także szereg różnic. Kuba leży bardzo blisko terytorium Stanów Zjednoczonych, gdzie obecna była dobrze zorganizowana grupa imigrantów kubańskich. Ponadto obydwa narody łączy wielkie zainteresowanie baseballem. Jak stwierdzili John Sugden, Alan Tomlinson i Eamon McCartan, paradoksem jest, że mimo znacznego antagonizmu pomiędzy USA a Kubą, do najważniejszych sportów w obu krajach należą baseball, koszykówka i boks. Są to sporty, które „przynieśli” na wyspę Amerykanie na przełomie XIX i XX wieku. Pokazuje to, iż społeczeństwo kubańskie pozostaje pod głębokim wpływem kultury USA pomimo oficjalnej nienawiści do tego $\mathrm{kraju}^{20}$. Te uwarunkowania w znacznym stopniu determinowały próby

19 W. Roszkowski, Pótwiecze. Historia polityczna świata po 1945 roku, Warszawa 2005, s. $101,103-104$.

20 J. Sugden, A. Tomlinson, E. McCartan, The Making and Remaking of White Lightning in Cuba: Politics, Sport, and Physical Education Thirty Years after the Revolution, [w:] The Social Roles of Sport in the Caribbean Societies, M.A. Malec (red.), New York 2008, s. 222. 
Mit dyplomacji pingpongowej w świetle przyszłych prób wykorzystania sportu...

wykorzystania sportu jako narzędzia dyplomatycznego pomiędzy Stanami Zjednoczonymi i Kubą. Co więcej, właśnie baseballa, a także koszykówki, dotyczyły najważniejsze próby powtórzenia sukcesu dyplomacji pingpongowej.

\section{Dyplomacja baseballowa}

Po rewolucji na Kubie nastąpił zanik kontaktów baseballowych pomiędzy dwoma krajami. Jednak już na początku lat 70. zaczęły pojawiać się pierwsze inicjatywy związane $\mathrm{z}$ ich ponownym nawiązaniem. W 1971 roku urodzony na Kubie menadżer zespołu San Diego Padres - Preston Gómez - ogłosił plan zabrania na Kubę w marcu tego roku drużyny gwiazd złożonej z Kubańczyków występujących w lidze MLB. Z inicjatywą taką wyszedł po tym, jak rok wcześniej odwiedził na Kubie swojego ojca, przy okazji mając okazję do spotkania z kubańskim przywódcą. Seria meczów miała mieć „wartość dla USA jako symbol dobrej woli". Zainteresowanie inicjatywą wyrazili komisarz ligi MLB Bowie Kuhn oraz działacze kubańscy. Departament Stanu USA nie wyraził jednak zgody na wyjazd drużyny z San Diego. Uznano, iż kontakt baseballowy na tak wysokim poziomie postawiłby administrację Richarda Nixona w trudnym położeniu, ponieważ musiałaby usprawiedliwiać inicjatywy odprężeniowe $\mathrm{z}$ otwarcie deklarowanym wrogiem. Ponadto, Amerykanie zbojkotowali także odbywające się na Kubie w tym samym roku amatorskie zawody Amateur World Series. Federacja amerykańska tłumaczyła to najpierw „delikatną sytuacją polityczną”, później natomiast kwestiami finansowymi ${ }^{21}$. Trzeba jednak zwrócić uwagę, iż wspomniana inicjatywa miała miejsce, jeszcze zanim doszło do dyplomacji pingpongowej. Jej zaistnienie w kwietniu 1971 roku i - zgodnie $\mathrm{z}$ hipotezą niniejszego artykułu - powstanie jej mitu, zmieniło sytuację, dając wyobrażenie o możliwościach wykorzystania sportu w celu zbliżania nieprzychylnych sobie państw.

Na początku 1975 roku, a więc już po sukcesie dyplomacji pingpongowej, pojawiła się kolejna inicjatywa - zaproponowana przez Prestona Gómeza i komisarza MLB Bowiego Kuhna, która także miała obejmować serię spotkań drużyny występujących w MLB Kubańczyków z drużynami kubańskimi. Inicjatywą taką mieli być zainteresowani działacze kubańscy ${ }^{22}$ - zresztą dokumenty potwierdzają, że w owym czasie przedstawiciele MLB kontaktowali się

${ }^{21}$ J.W.R. Turner, Baseball Diplomacy, Baseball Deployment: The National Pastime in U.S. Cuba Relations, Tuscaloosa 2012, s. 131-133; R. Elias, The Empire Strikes Out. How Baseball Sold U.S. Foreign Policy and Promoted the American Way Abroad, New York 2010, s. 236.

22 J.W.R. Turner, op. cit., s. 144-147. 
bezpośrednio z kubańskim ministerstwem sportu, poza oficjalnymi kanałami dyplomatycznymi ${ }^{23}$. Należy w tym miejscu zwrócić uwagę, iż ta i inne próby nawiązania kontaktów baseballowych miały oddolny charakter i były proponowane najczęściej przez osoby związane $\mathrm{z}$ klubami sportowymi czy z ligą MLB, nie zaś $\mathrm{z}$ administracją rządową. To mechanizm typowy dla dyplomacji publicznej, która często jest prowadzona bezpośrednio przez jednostki czy organizacje społeczne, jedynie zaś koordynowana przez władze państwowe.

W związku z nową inicjatywą wywiązała się bardzo intensywna wymiana korespondencji pomiędzy B. Kuhnem, asystentem sekretarza w Departamencie Stanu Williamem Rogersem i sekretarzem stanu Henrym Kissingerem. Starania o wysłanie drużyny gwiazd na Kubę czynił Kuhn, który spotkał się nawet w związku z tym w lutym 1975 roku w Meksyku z działaczami kubańskimi celem ustalenia szczegółów. Rogers zdawał się popierać jego inicjatywę, natomiast przeciwny był Kissinger ${ }^{24}$. Kiedy Kissinger spytał Rogersa, dlaczego popiera tournée, ten odpowiedział:

Krok z zakresu public relations mógłby naprawić niektóre zniekształcenia w publicznym postrzeganiu naszej polityki kubańskiej - przenosząc akcenty na sfery niepolityczne i niekontrowersyjne. Chińscy zawodnicy ping-ponga zostali zaakceptowani przez amerykańską opinię publiczną jako dobry sposób na przełamanie lodów między krajami podzielonymi dekadami wrogości. Baseball z Kubą mógłby służyć podobnemu celowi, budując most pomiędzy Zatoką Świń a nowymi stosunkami z Castro. [...] Wybranie sportu, w którym mamy duże szanse wygrać byłoby dobrze przyjęte przez Amerykanów zmartwionych zwycięstwami komunistów na igrzyskach olimpijskich. Mecz byłby widziany jako sprytny polityczny krok Jankesów ${ }^{25}$.

W wypowiedzi tej, w której nawiązano do dyplomacji pingpongowej, dostrzec można, jak silny oddźwięk pozostawiła ona w świadomości Amerykanów, $\mathrm{w}$ tym przedstawicieli administracji rządowej, stając się niejako wyznacznikiem potencjału sportu w dziedzinie dyplomacji i argumentem na rzecz popierania kolejnych, podobnych prób.

Problemem dla Departamentu Stanu pozostawał jednak brak gestów dobrej woli ze strony Kuby, dzięki czemu kontakt baseballowy mógłby być określony jako odpowiedź na niego. Mimo to Departament wydawał się mocno zainteresowany inicjatywą. Ostatecznie 24 lutego 1975 roku sekretarz stanu Henry

23 T.F. Carter, J. Sugden, op. cit., s. 109.

24 J.P. Sugden, Sport and Spies: The Dark Side of Sport and International Relations, [w:] Image, Power and Space. Studies in Consumption and Identity, A. Tomlinson, J.M. Woodham (red.), New York 2007, s. 49; M.H. Jamail, „One Day when the Yankees...”: Cuba Baseball, the United States and the Cold War, [w:] East Plays West. Sport and the Cold War, S. Wagg, D.L. Andrews (red.), Abingdon 2007, s. 200.

25 J.P. Sugden, op. cit., s. 49-50; J.W.R. Turner, op. cit., s. 151-153. 
Kissinger odwołał mecz, pomimo argumentacji Rogersa, prawdopodobnie obawiając się nacisków ze strony potężnego, antykubańskiego republikańskiego lobby ${ }^{26}$. W kontekście przytoczonej wyżej wypowiedzi, warto zwrócić uwagę na motywację ewentualnego nawiązania kontaktu baseballowego. William Rogers zwrócił bowiem uwagę na możliwość przekonania społeczeństwa do zmiany dotychczasowej linii politycznej względem Kuby, co jest celem bardzo zbliżonym do sytuacji dyplomacji pingpongowej z perspektywy amerykańskiej. Jednocześnie jednak zwrócono uwagę na prestiż związany z oczekiwanym zwycięstwem sportowym. Takie podejście, jak się wydaje, może ujawniać problemy ze skutecznością dyplomacji baseballowej pomiędzy USA a Kubą, bowiem żadna ze stron nie miała na celu wyłącznie ocieplenia relacji, ale także uzyskanie korzyści wizerunkowych „kosztem” partnera dzięki sportowemu zwycięstwu.

W późniejszym czasie pojawiały się kolejne inicjatywy związane z nawiązaniem kontaktów baseballowych, jednak nieustannie na drodze ich realizacji stał Departament Stanu. Co prawda, od 1987 roku organizowano coroczne serie spotkań, naprzemiennie na Kubie i w USA ${ }^{27}$, jednak dotyczyły one drużyn amatorskich i - co za tym idzie - ich wydźwięk dyplomatyczny był ograniczony. Swoisty przełom nastąpił dopiero po wizycie na Kubie papieża Jana Pawła II w 1998 roku, po którym nastąpiła pozytywna zmiana nastawienia administracji Billa Clintona względem Kuby. Od stycznia 1999 roku postanowiono zezwolić na intensyfikację kontaktów międzyludzkich z Kubą, zwiększając kontakty kulturalne, w tym sportowe ${ }^{28}$. Nowe okoliczności zostały wykorzystane przez właściciela drużyny Baltimore Orioles Petera Angelosa, który poszukiwał możliwości zagrania z reprezentacją Kuby od 1995 roku, jednak wówczas Departament Stanu nie wydał pozwolenia na kontakty na tak wysokim poziomie. Angelosowi zajęło aż trzy lata doprowadzenie do szansy realizacji swojego celu. Pojawiła się w związku z tym informacja ze strony administracji USA o możliwości zagrania przez Orioles jednego meczu w Hawanie i rewanżu w USA na stadionie Baltimore Camden Park. Najważniejszym celem administracji USA było to, aby rząd Kuby nie korzystał ekonomicznie na meczach, zgodnie $\mathrm{z}$ hard currency denial policy. Przeciwna meczom Rada Bezpieczeństwa Narodowego USA ostatecznie ustąpiła po tym, jak sekretarz stanu Madeleine Albright stwierdziła, że mecze miały na celu „dać mieszkańcom

26 Ibidem.

27 Ibidem, s. 208, 210-213, 216.

${ }^{28}$ Jest to określane jako January 5 measures. Patrz: M.P. Sullivan, Cuba: U.S. Restrictions on Travel and Remittances, CRS Report for Congress, 7.01.2011, s. 4; M. Morley, C. McGillion, Unfinished Business. America and Cuba after the Cold War, 1989-2001, Cambridge 2002, s. 149. 
Kuby nadzieję w ich walce"29. Administracja Clintona zezwoliła na mecze pod warunkiem, że fundusze przeznaczone na ich organizację zostaną przekazane na cele humanitarne ${ }^{30}$. Kuba proponowała przeznaczenie dochodów dla ofiar huraganów w Ameryce Południowej ${ }^{31}$. Albright ustaliła także, że fundusze dla Kuby w związku z meczem zostaną przekazane Caritasowi jako ich administratorowi ${ }^{32}$.

Kiedy podano do wiadomości informację, że mecz Orioles rzeczywiście ma dojść do skutku, pojawiła się krytyka takiej decyzji ze strony niektórych organizacji imigrantów kubańskich w USA. Departament Stanu USA twierdził, iż decyzja, aby zagrać jeden mecz w Hawanie, nie może być postrzegana jako „nagroda” dla rządu Kuby, ponieważ „nie ma zachowania, które można nagradzać". Administracja USA stwierdziła ponadto, iż nie był to wstęp do normalizacji stosunków w stylu dyplomacji pingpongowej. Ponadto władze amerykańskie sugerowały, iż mecze ułatwią rozbudowę procesu zaangażowania międzyludzkiego (people-to-people engagement), czego ostatecznym celem jest promocja demokracji na Kubie ${ }^{33}$. Co prawda, nie nawiązywano bezpośrednio do sukcesu dyplomacji pingpongowej, ale jej obecność w świadomości zbiorowej Amerykanów jest tak głęboko zakorzeniona, że i tak o niej wspominano podczas rozważań nad słusznością inicjatywy.

\section{Dyplomacja koszykarska}

Jeśli chodzi o amerykańsko-kubańskie kontakty sportowe w celach dyplomatycznych obok wspomnianego wcześniej baseballa starano się wykorzystać także koszykówkę. Dyplomacja koszykarska pomiędzy Stanami Zjednoczonymi a Kubą, podobnie jak dyplomacja baseballowa, z perspektywy amerykańskiej także wyrosła $\mathrm{z}$ wielkiej fascynacji sukcesem dyplomacji pingpongowej.

Okoliczności związane z dyplomacją koszykarską są ściśle powiązane $\mathrm{z}$ uwarunkowaniami politycznymi, jakie zaszły w połowie drugiej połowie lat 70. W styczniu 1977 roku stanowisko prezydenta Stanów Zjednoczonych objął Jimmy Carter. Już na początku swojej pracy w prezydenckiej dyrektywie stwierdził, iż widzi konieczność normalizacji stosunków z Kubą. Jednak

\footnotetext{
29 M. Morley, C. McGillion, op. cit., s. 149-150.

30 R. Elias, op. cit., s. 241.

31 I.L. Horowitz, The Long Night of Dark Intent. A Half Century of Cuban Communism, New Brunswick 2011, s. 482.

32 M. Morley, C. McGillion, op. cit., s. 150.

33 Ibidem, s. 152; S.E. Eckstein, The Immigrant Divide. How Cuban Americans Changed the US and Their Homeland, New York 2009, s. XXXIII.
} 
pomimo tej dyrektywy droga do polepszenia relacji była trudna i skomplikowana. W związku z tym nowa administracja amerykańska rozpoczęła wysyłanie sygnałów w stronę reżimu Castro, np. gdy w jednej z wypowiedzi sekretarz stanu Cyrus Vance skrytykował embargo nałożone przez Kubę, określając je jako nieskuteczne. Gesty czynili także Kubańczycy. Pod koniec stycznia 1977 roku za pośrednictwem dyplomatów szwajcarskich zaproponowali rozmowy na temat rybołówstwa i granic morskich. Amerykanie odpowiedzieli, iż są także zainteresowani rozmowami na temat traktatu skierowanego przeciwko porwaniom samolotów. Carter zawiesił również loty zwiadowcze nad Kubą, natomiast Cyrus Vance miał pozwolić, aby zakaz podróży na Kubę (oraz do trzech innych krajów) wygasł ${ }^{34}$. W nawiązaniu do takiego rozwoju wydarzeń, w marcu i kwietniu po raz pierwszy od 15 lat Amerykanie i Kubańczycy prowadzili bezpośrednie negocjacje, które zgodnie z wcześniejszą propozycją strony kubańskiej dotyczyły granicy morskiej i rybołówstwa. Obydwa kraje otworzyły także w stolicy partnera tzw. diplomatic interest sections, czyli jednostki dyplomatyczne otwierane przez jedno państwo przy ambasadzie drugiego państwa $\mathrm{w}$ państwie trzecim - w sytuacjach, gdy państwa pierwsze i trzecie nie mają bezpośrednich kontaktów dyplomatycznych ${ }^{35}$.

Jednym z gestów, jakie poczyniła amerykańska administracja w kierunku Kuby, była zgoda Departamentu Stanu z marca 1977 roku, aby koszykarze z Uniwersytetu Południowej Dakoty oraz Stanowego Uniwersytetu Południowej Dakoty odbyli podróż na Kubę, gdzie mieli rozegrać serię meczów pokazowych ${ }^{36}$. Inicjatywa z tym związana miała jednak miejsce już wcześniej, bowiem w 1975 roku. Wówczas to doszło do spotkań kubańskiego dyktatora Fidela Castro z amerykańskimi senatorami Jamesem Abourezkiem i Georgeem McGovernem i od tego czasu podejmowane były pierwsze kroki mające na celu zorganizowanie wizyty ${ }^{37}$. Inicjatywa wysłania na Kubę drużyny męskiej

34 W.M. LeoGrande, P. Kornbluh, Back Channel to Cuba. The Hidden History of Negotiations Between Washington and Havana, Chapel Hill 2014, s. 155, 157.

35 D. Moreno, U.S. Policy in Central America. The Endless Debate, St. Gainesville 1990, s. 37.

36 W.M. LeoGrande, P. Kornbluh, op. cit., s. 157; South Dakota College Team Gets OK to Travel to Cuba, „Milwaukee Sentinel” 1977, 5.03., s. $2 / 1$.

37 UA 46.1 Cuba Trip Collection, Athletic Department, South Dakota State University, 8.05.1998, http://libguides.sdstate.edu/content.php?pid=378739\&sid=3102369 [dostęp: 2.04.2015]; B. Dunsmoor, Abourezk Applauds Normalized Relations With Cuba, 18.12.2014, http:// www.keloland.com/newsdetail.cfm/abourezk-applauds-normalized-relations-with-cuba/?id=173428 [dostęp: 2.04.2015]; idem, Abourezk Supports Obama's Efforts On Cuba, 18.12.2014, http://www.keloland.com/newsdetail.cfm/abourezk-supports-obamas-effortson-cuba/?id=173451 [dostęp: 2.04.2015]; K.K. Skinner, A. Anderson, M. Anderson (red.), Reagan In His Own Hand. The Writing of Ronald Reagan that Revealed His Revolutionary Vision for America, New York 2001, s. 183. 
koszykówki początkowo miała dotyczyć Stanowego Uniwersytetu Południowej Dakoty, jednak za sprawą wspomnianych senatorów Abourezka i McGoverna wyjazd stał się wspólnym przedsięwzięciem dwóch uczelni - wspomnianej powyżej oraz Uniwersytetu Południowej Dakoty. Planowanie miało nabrać tempa w marcu 1977 roku, zaś do samej wizyty doszło w dniach 4-8 kwietnia $1977 \mathrm{roku}^{38}$.

Wizyta koszykarskiej delegacji z Dakoty Południowej liczyła 100 osób. Jak miał zażartować Abourezk podczas wyprawionego przez kubańskie ministerstwo sportu bankietu dla gości, była to największa grupa Amerykanów odwiedzająca Kubę od czasu inwazji w Zatoce Świń ${ }^{39}$. Pod względem politycznym kluczowymi postaciami w grupie byli amerykańscy senatorowie z Dakoty Południowej George McGovern i James Abourezk. Postrzegali wizytę jako „formę dyplomacji koszykarskiej mającą wybudować most nad szesnastoletnią wyrwą w relacjach amerykańsko-kubańskich", a także nie ukrywali, iż w ich mniemaniu „ma ona otworzyć drzwi, tak jak dyplomacja pingpongowa doprowadziła do bliższych relacji pomiędzy USA a komunistycznymi Chinami”. Atmosfera spotkań była określana przez dziennikarzy jako pozytywna, Kubańczycy zaś mieli okazać się bardzo gościnni ${ }^{40}$. Warto zwrócić uwagę, iż wspomniana gościnność gospodarzy wydaje się typowa dla przejawów dyplomacji sportowej pomiędzy państwami pragnącymi ocieplić wzajemne stosunki. Była bowiem widoczna także we wcześniej opisywanych dyplomacjach: pingpongowej pomiędzy USA a Chinami oraz amerykańsko-kubańskiej dyplomacji baseballowej. Ponadto należy zwrócić uwagę, iż główni inicjatorzy wymiany - amerykańscy senatorowie McGovern i Abourezk - nie ukrywali, iż jej celem od początku była próba popierania zbliżenia pomiędzy Stanami Zjednoczonymi a Kubą.

\section{Upamiętnianie dyplomacji pingpongowej}

O mitycznym znaczeniu dyplomacji pingpongowej świadczą nie tylko próby powtórzenia jej sukcesu, do których dochodziło w USA później, ale także bezpośrednie nawiązania do niej, chociażby poprzez obchody rocznicowe tego wydarzenia. W pierwszej kolejności warto jednak wspomnieć o niejako drugim etapie dyplomacji baseballowej, do jakiego doszło na rok po właściwych,

38 UA 46.1 Cuba Trip...

39 J.G. Abourezk, Advise \& Dissent. Memoirs of South Dakota and the U.S. Senate, Chicago 1989, s. 235.

40 J. Platero, Cuba, U.S. Play Diplomats While Ball Bounces, „The Daily Item” 1977, 5.04., s. 10B; Renewal of Ties with Cuba Urged, „The Tuscaloosa News” 1977, 10.04., s. 12A. 
opisanych wyżej wydarzeniach. Tak więc, wiosną 1972 roku reprezentacja Chin złożyła rewizytę w Stanach Zjednoczonych.

W USA zakładano, i to już w momencie zaproszenia Amerykanów do Chin, iż naturalnym rozwojem wydarzeń będzie zaproszenie do USA drużyny tenisa stołowego z Chin. Taka też informacja została przekazana Chińczykom, jeszcze zanim amerykańscy tenisiści stołowi wyruszyli do Pekinu w 1971 roku. Rewizytę, na którą strona chińska wyraziła zgodę, przygotowywał Amerykański Związek Tenisa Stołowego USTTA przy wsparciu Narodowego Komitetu Stosunków Amerykańsko-Chińskich. Kontakty związane z organizacją przyjazdu realizowano głównie na linii pozarządowej, z bardzo nieznacznym bezpośrednim zaangażowaniem Białego Domu. Pojawiały się przy tym problemy, chociażby dotyczące terminu wizyty - Chińczycy mieli sugerować chęć przyjazdu w okresie kwitnienia kwiatów. Dopiero w połowie marca 1972 roku strona chińska poinformowała, że 10 kwietnia do USA przybędzie 26 członków drużyny tenisa stołowego (zawodnicy byli osobiście wybrani przez Zhou Enlaia) i sześciu przedstawicieli mediów. Ostatecznie wizyta odbyła się między 12 a 29 kwietnia ${ }^{41}$. W jej trakcie rozegrano serię meczów towarzyskich pod nazwą „Najpierw Przyjaźn'” (oryg. Friendship First, tłumaczenie własne $)^{42}$.

W kolejnych latach wielokrotnie dochodziło do organizacji obchodów rocznic dyplomacji pingpongowej. Na szczególną uwagę zasługują obchody 25. i 40. rocznicy. W ramach obchodów tej pierwszej wizytę w USA złożyła delegacja chińska, zaś w Chinach delegacja amerykańska. Obchody rozpoczęło przyjęcie powitalne w siedzibie Organizacji Narodów Zjednoczonych w Nowym Jorku, zorganizowane przez Narodowy Komitet Stosunków AmerykańskoChińskich, jednego z organizatorów tournée chińskich tenisistów stołowych w USA w 1972 roku. W obchodach brali udział Henry Kissinger, członkowie rodziny prezydenta Richarda Nixona, sportowcy biorący udział w dyplomacji pingpongowej, czynni sportowcy z obu krajów ${ }^{43}$. W jej ramach rozegrano także mecz pokazowy w siedzibie ONZ w Nowym Jorku ${ }^{44}$.

$\mathrm{W}$ ramach upamiętnienia 40. rocznicy dyplomacji pingpongowej obchody w obu krajach organizowały obie federacje tenisa stołowego, przy współpracy

${ }^{41}$ Xu Guoqi, op. cit., s. 148-151.

42 J. Basu, Ping-pong Diplomacy Returns to Stanford after 25 Years, „Stanford News” 1997, 15.07., http://news.stanford.edu/pr/97/970715pingpong.html [dostęp: 6.06.2016].

43 J. Hoarfrost, 25th Anniversary of Ping Pong Diplomacy, Paddle Palace, http://blog.paddlepalace.com/1997/04/25th-anniversary-of-ping-pong-diplomacy/ [dostęp: 7.06.2016].

44 Ban Ki-moon, Remarks Prepared for Delivery at the United Nations Correspondents Association Dinner, United nations Statements, 2.12.2005, http://www.un.org/sg/ statements/?nid=1814 [dostęp: 6.06.2016]. 
ze strony Narodowych Komitetów Olimpijskich - na podstawie porozumienia o współpracy. W USA zaplanowano obchody w lipcu 2011 roku, w trakcie których odbyć się miały m.in. mecze w ramach 2011 US Table Tennis Open w Milwaukee oraz wizyta w muzeum sztuki w Milwaukee. Zaplanowano także wydarzenia kulturalne w San Francisco oraz wizytę w bibliotece Richarda Nixona w Yerba Linda w Kalifornii. Z kolei obchody w Chinach ustalono na październik tego samego roku. W obchodach brali udział sportowcy uczestniczący we właściwej dyplomacji pingpongowej, a także czynni sportowcy, dzialacze, trenerzy itp. ${ }^{45}$.

\section{Konkluzje}

W niniejszym artykule dokonano analizy dyplomacji pingpongowej z perspektywy jej uobecnienia się jako mitu w świadomości zbiorowej społeczeństwa amerykańskiego. Analizie poddano w szczególności próby powtórzenia jej politycznego sukcesu, jakie czynione były od lat 70 . w odniesieniu do relacji z Kubą, ale także sposoby upamiętniania dyplomacji pingpongowej.

Jak wskazano, pojawił się cały szereg inicjatyw związanych z chęcią powtórzenia sukcesu dyplomacji pingpongowej. Chciano w tym celu wykorzystywać kontakty w baseballu i w koszykówce - dwóch dyscyplinach sportowych, które zarówno w USA, jak i na Kubie cieszyły się stosunkową dużą popularnością, co stanowi zarazem pewną różnicę względem dyplomacji pingpongowej. Należy w związku z tym zwrócić uwagę, iż inicjatywy te miały charakter oddolny, zaś ich niepowodzenia najczęściej uwarunkowane były brakiem zgody ze strony Departamentu Stanu. Nasuwa się w związku z tym wniosek, iż mit dyplomacji pingpongowej silniej zakorzeniony został w społeczeństwie amerykańskim niż wśród przedstawicieli elity władzy. Tym niemniej także przedstawiciele establishmentu amerykańskiego w swoich rozważaniach na temat wyrażenia zgody na kontakty sportowe nawiązywali właśnie do sukcesu dyplomacji pingpongowej.

Poza inicjatywami powtórzenia sukcesu dyplomacji pingpongowej wiele wskazuje, iż wydarzenie to bardzo silnie uobecniło się w świadomości Amerykanów. Świadczy o tym także częste nawiązywanie do niego. Można to dostrzec w produktach kultury masowej, w wielości opracowań naukowych czy też w obchodach rocznicowych upamiętniających ją. Biorąc to wszystko pod

45 P.M. Miller, Ping Pong Diplomacy Lives On, „China Business Review” 2011, July-September, s. 61; R. Wilkey, San Francisco Ping Pong Tournament: Mayor Hosts City's First Game Of Citywide Pong, „Huffington Post” 2011, 13.09., http://www.huffingtonpost. com/2011/09/13/san-francisco-ping-pong_n_961114.html [dostęp: 6.06.2016]. 
Mit dyplomacji pingpongowej w świetle przyszłych prób wykorzystania sportu...

uwagę, hipoteza zakładająca mityczność dyplomacji pingpongowej w społeczeństwie amerykańskim wydaje się uprawdopodobniona.

W świetle powyższych analiz można stwierdzić, iż dyplomacja pingpongowa może być uznawana w Stanach Zjednoczonych nie tylko za mit, ale także - jak określił to Pierre Norra - miejsce pamięci, które ów autor rozumiał nie tylko w sensie terytorialnym, ale także symbolicznym ${ }^{46}$, jako punkty utwierdzone w wyobrażeniach zbiorowych ${ }^{47}$. Jej obecność w świadomości zbiorowej Amerykanów jest bowiem bardzo głęboka, o czym świadczą przytoczone fakty.

\section{Bibliografia}

Abourezk J.G., Advise \& Dissent. Memoirs of South Dakota and the U.S. Senate, Chicago 1989.

Axelrod A., The Real History of the Cold War. A New Look at the Past, New York 2009.

Ban Ki-moon, Remarks Prepared for Delivery at the United Nations Correspondents Association Dinner, United Nations Statements, 2.12.2005, http:// www.un.org/sg/statements/?nid=1814 [dostęp: 6.06.2016].

Basu J., Ping-pong Diplomacy Returns to Stanford after 25 Years, „Stanford News" 1997, 15.07., http://news.stanford.edu/pr/97/970715pingpong.html [dostęp: 6.06.2016].

Bjola C., Kornprobst M., Understanding International Diplomacy. Theory, Practice and Ethics, Abingdon 2013.

Carter T.F., Sugden J., The USA and Sporting Diplomacy: Comparing and Contrasting the Cases of Table Tennis with China and Baseball with Cuba in the 1970s, „International Relations” 2011, no. 26, s. 101-121.

DeVoss D.A., Ping-Pong Diplomacy, „Smithsonian Magazine” 2002, http:// www.smithsonianmag.com/history/ping-pong-diplomacy-60307544/?no-ist [dostęp: 6.06.2016].

Dunsmoor B., Abourezk Applauds Normalized Relations With Cuba, 18.12.2014, http://www.keloland.com/newsdetail.cfm/abourezk-applauds-normalized-relations-with-cuba/?id=173428 [dostęp: 2.04.2015].

Dunsmoor B., Abourezk Supports Obama's Efforts On Cuba, 18.12.2014, http:// www.keloland.com/newsdetail.cfm/abourezk-supports-obamas-efforts-oncuba/?id=173451 [dostęp: 2.04 .2015$]$.

46 P. Nora, Between Memory and History: Les Lieux de Mémoire, „Representations” 1989, no. 26, s. 18-19.

47 M. Todorova, Dizanje prošlosti u vazduh. Ogledi o Balkanu i Istočnoj Evropi, Beograd 2010, s. 143-145. 
Eckstein S.E., The Immigrant Divide. How Cuban Americans Changed the US and Their Homeland, New York 2009.

Elias R., The Empire Strikes Out. How Baseball Sold U.S. Foreign Policy and Promoted the American Way Abroad, New York 2010.

Espy R., The Politics of the Olympic Games. With Epilogue, 1976-1980, Berkeley-Los Angeles-London 1981.

Fang Hong, Xiong Xiaozheng, Communist China: Sport, Politics and Diplomacy, [w:] Sport in Asian Society. Past and Present, J.A. Mangan, F. Hong (red.), Oxon-New York 2003, s. 319-342.

Goldstein J.S., Freeman J.R., Three-Way Street. Strategic Reciprocity in World Politics, Chicago 1990.

Griffin N., Ping-Pong Diplomacy. The Secret History Behind the Game that Changed the World, New York 2014.

Guoqui X., Olympic Dreams. China and Sports 1895-2008, Cambridge-London 2008.

Hoarfrost J., 25th Anniversary of Ping Pong Diplomacy, Paddle Palace, http:// blog.paddlepalace.com/1997/04/25th-anniversary-of-ping-pong-diplomacy/ [dostęp: 7.06.2016].

Horowitz I.L., The Long Night of Dark Intent. A Half Century of Cuban Communism, New Brunswick 2011.

Jamail M.H., „One Day when the Yankees...”: Cuban Baseball, the United States and the Cold War, [w:] East Plays West. Sport and the Cold War, S. Wagg, D.L. Andrews (red.), Abingdon 2007, s. 187-206.

Johns A.L., Introduction. Competeing in the Global Arena: Sport and Foreign Relations since 1945, [w:] Diplomatic Games. Sport, stagecraft, and international relations since 1945, H.L. Dichteri, A.L. Johns (red.), Lexington 2014, s. 1-16.

Ladley E., Nixon's China Trip, Lincoln 2002.

LeoGrande W.M., Kornbluh P., Back Channel to Cuba. The Hidden History of Negotiations Between Washington and Havana, Chapel Hill 2014.

McGillion C., Unfinished Business. America and Cuba after the Cold War, 19892001, Cambridge 2002.

Miller P.M., Ping Pong Diplomacy Lives On, „China Business Review” 2011, July-September.

Moreno D., U.S. Policy in Central America. The Endless Debate, St. Gainesville 1990.

Nora P., Between Memory and History: Les Lieux de Mémoire, „Representations" 1989 , no. 26, s. 7-24.

Pigman G.A., Contemporary Diplomacy, Cambridge 2010.

Platero J., Cuba, U.S. Play Diplomats While Ball Bounces, „The Daily Item” 1977, 5.04 . 
Mit dyplomacji pingpongowej w świetle przyszłych prób wykorzystania sportu...

Renewal of Ties with Cuba Urged, „The Tuscaloosa News” 1977, 10.04.

Roszkowski W., Półwiecze. Historia polityczna świata po 1945 roku, Warszawa 2005.

Skinner K.K., Anderson A., Anderson M. (red.), Reagan In His Own Hand. The Writing of Ronald Reagan that Revealed His Revolutionary Vision for America, New York 2001.

South Dakota College Team Gets OK to Travel to Cuba, „Milwaukee Sentinel” 1977, 05.03.

Sugden J.P., Sport and Spies: The Dark Side of Sport and International Relations, [w: Image, Power and Space. Studies in Consumption and Identity, A. Tomlinson, J.M. Woodham (red.), New York 2007, s. 41-64.

Sugden J., Tomlinson A., McCartan E., The Making and Remaking of White Lightning in Cuba: Politics, Sport, and Physical Education Thirty Years after the Revolution, [w:] The Social Roles of Sport in the Caribbean Societies, M.A. Malec (red.), New York 2008, s. 211-228.

Sullivan M.P., Cuba: U.S. Restrictions on Travel and Remittances, CRS Report for Congress, 7.01.2011.

Todorova M., Dizanje prošlosti u vazduh. Ogledi o Balkanu i Istočnoj Evropi, Beograd 2010.

Turner J.W.R., Baseball Diplomacy, Baseball Deployment: The National Pastime in U.S. Cuba Relations, Tuscaloosa 2012.

UA 46.1 Cuba Trip Collection, Athletic Department, South Dakota State University, 08.05.1998, http://libguides.sdstate.edu/content.php?pid=378739 \&sid=3102369 [dostęp: 18.12.2014].

Wilkey R., San Francisco Ping Pong Tournament: Mayor Hosts City's First Game Of Citywide Pong, „Huffington Post” 2011, 13.09., http://www.huffingtonpost.com/2011/09/13/san-francisco-ping-pong_n_961114.html [dostęp: 6.06.2016].

Yafeng X., Negotiating with the Enemy. U.S. - China Talks during the Cold War, 1949-1972, Bloomington 2006. 


\begin{abstract}
The aim of the article is to investigate the ways of using sport in order to shape international brand of a state. Accordingly, various forms of shaping state's international image with the use of sports diplomacy have been analyzed and shortly described - within the proposed typology. An attempt to verify a hypothesis concerning sports diplomacy as a significant tool of shaping state's international brand was also made.
\end{abstract}

Keywords: sports diplomacy, nation's brand, sport, public diplomacy 